\title{
Hematological alterations in Astyanax altiparanae (Characidade) caused by Lernaea cyprinacea (Copepoda: Lernaeidae)
}

\author{
Lincoln L. Corrêa ${ }^{1, *}$, Marcos Tavares-Dias ${ }^{2}$, Paulo S. Ceccarellii ${ }^{3}$, \\ Edson A. Adriano ${ }^{4,5}$ \\ ${ }^{1}$ Universidade Federal do Oeste do Pará (UFOPA), Instituto de Ciências e Tecnologia das Águas (ICTA), \\ Avenida Mendonça Furtado $n^{\circ}$ 2946, Santarém, PA, Brazil \\ ${ }^{2}$ Embrapa Amapá, Macapá, AP, Brasil, Rodovia Juscelino Kubitschek, km 5, 2600, CEP 68903-419, Macapá, AP, Brazil \\ ${ }^{3}$ Centro Nacional de Pesquisa e Conservação de Peixes Continentais (CEPTA), Instituto Chico Mendes de \\ Conservação da Biodiversidade (ICMBio), Rod. SP 201, km 6.5, Caixa Postal 64, CEP 13630-970, Pirassununga, SP, Brazil \\ ${ }^{4}$ Departamento de Ciências Biológicas, Universidade Federal de São Paulo (Unifesp), Rua Professor Artur Riedel, 275, \\ Jardim Eldorado, CEP 09972-270, Diadema, SP, Brazil \\ ${ }^{5}$ Departamento de Biologia Animal, Instituto de Biologia, Universidade Estadual de Campinas (UNICAMP), Caixa Postal \\ 6109, CEP 13083-970 Campinas, SP, Brazil
}

\begin{abstract}
This study describes the hematological alterations in Astyanax altiparanae associated with infestation with Lernaea cyprinacea. The study was carried out in a lagoon of the MogiGuaçu River, in the municipality of Pirassununga, in the state of São Paulo, Brazil. Of 46 fish examined, $45.6 \%$ had their integument infested by L. cyprinacea, with a mean intensity of 4.9 parasites per fish and a mean abundance of 2.2, giving a total of 139 recovered crustaceans. The abundance of $L$. cyprinacea correlated positively with the length and weight of the hosts, and the intensity of infestation was higher in female hosts. Macroscopic observation of lesions associated with the parasite showed a severe inflammatory reaction around the site of attachment of L. cyprinacea, associated with a lower relative condition factor and blood parameters. The hematocrit, number of red blood cells and thrombocytes were higher in non-parasitized than in parasitized fish. However, the hemoglobin concentration, hematimetric indices and the number of white blood cells were not influenced by infestation.
\end{abstract}

KEY WORDS: Ectoparasites $\cdot$ Hematology $\cdot$ Infestation $\cdot$ Continental fish

Resale or republication not permitted without written consent of the publisher

\section{INTRODUCTION}

Among fish of the family Characidae, the genus Astyanax Baird \& Girard (1854) is the most widely dispersed in the Neotropical region. This genus includes around a hundred species (Garutti \& Britski 2000), which are popularly known as banded astyanax and banded tetra (and in Brazil as lambari or tambiú). The species A. altiparanae Garutti \& Britski, 2000 (Syn.: A. bimaculatus) is a very common fish in the rivers and streams of the upper Paraná River basin (Nomura 1975, Garutti \& Britski 2000).

Lernaea cyprinacea Linnaeus, 1758 is a copepod crustacean that infests the integument, gills, eyes, fins, nostrils and mouth of fish (Medeiros \& Maltchik 1999, Gabrielli \& Orsi 2000, Thatcher 2006, Raissy et al. 2013). This parasite is one of the most commonly observed parasites in fishes, causing bleeding and necrosis, especially in the gills, which can result in decreased respiratory efficiency (Thatcher 2006, 
Gallio et al. 2007, Raissy et al. 2013). Often such damage can lead to secondary infections caused by bacteria and fungi in hosts (Gabrielli \& Orsi 2000, Thatcher 2006, Gallio et al. 2007, Raissy et al. 2013). Heavy infestations may cause mass mortalities of wild and farmed fish and make the fish undesirable to anglers, thus affecting fishery management targets (Thatcher 2006, Raissy et al. 2013). L. cyprinacea was introduced to Brazil along with carps imported from Hungary, and presently these parasites can be found infesting diverse wild fish populations in various hydrographic basins of the country (Medeiros \& Maltchik 1999, Gabrielli \& Orsi 2000, Gallio et al. 2007).

In fish populations, blood parameters can be important tools for understanding the physiology and oxygen carrying capacity, as well as the immune system, of fish (Tavares-Dias \& Moraes 2007, Ranzani-Paiva et al. 2013). Therefore, blood cell parameters may be good indicators of the health status of a fish population (Nair \& Nair 1983, Tavares-Dias et al. 2007, Ranzani-Paiva et al. 2013). However, few studies have addressed the effects of the infestation of parasitic crustaceans on the hematological parameters of fish (Nair \& Nair 1983, Silva-Souza et al. 2000, TavaresDias et al. 2007, Fajer-Ávila et al. 2011, PeñaRehbein et al. 2013). This study investigated the effect of moderate levels of infection by L. cyprinacea on the hematological parameters of $A$. altiparanae from the Mogi-Guaçu River, part of the upper Paraná River basin (Brazil). of the caudal vessel using a syringe containing heparin sodium $25000 \mathrm{IU} \mathrm{ml}^{-1}$. The blood was used to determine the concentration of hemoglobin, hematocrit and the total red blood cell (RBC) number (Ranzani-Paiva et al. 2013). These parameters were used to determine hematimetric indices such as mean corpuscular volume (MCV), mean corpuscular hemoglobin $(\mathrm{MCH})$ and mean corpuscular hemoglobin concentration (MCHC). Blood smears stained with May-Grunwald-Giemsa were used to evaluate total white blood cell counts and total thrombocyte counts (Ranzani-Paiva et al. 2013).

Body weight $(\mathrm{g})$, total length $(\mathrm{cm})$ and sex of each fish were determined (Vazzoler 1996). Weight and total length were used to calculate the relative condition factor $\left(K_{n}\right)$ of the host and to calculate the lengthweight relationship $\left(W=a L^{b}\right)$, following logarithmic transformation of length and weight and subsequent adjustment, thereby obtaining $\ln (y)=\ln a+b \ln (x)($ Le Cren 1951).

The collection and quantification of L. cyprinacea were performed. The parasites were fixed in formalin $(10 \%)$, preserved in alcohol (70\%) glycerin and then clarified in lactophenol for identification (Eiras et al. 2006). Subsequently, the parasites were photographed using a Leica light microscope coupled to a computer equipped with the IM50 software (Leica). The ecological terms used followed previous recommendations (Rohde et al. 1995, Bush et al. 1997). Following identification, representative specimens of the parasites were deposited in the Zoological

\section{MATERIALS AND METHODS}

In August 2012, 46 specimens of Astyanax altiparanae were caught in a lagoon of the Mogi-Guaçu River, in the municipality of Pirassununga, in the state of Sao Paulo, Brazil $\left(21^{\circ} 55^{\prime}\right.$ 55" S, $47^{\circ} 22^{\prime} 37^{\prime \prime} \mathrm{W}$ ) (Fig. 1). Fish were caught with gillnets of different meshes (5, 10 and $12 \mathrm{~mm}$ ) and transported in a 5001 plastic box to the Freshwater Fish Hematology Laboratory of CEPTA/ICMBio to collect samples of blood and Lernaea cyprinacea. This study was developed in accordance with the principles adopted by the Brazilian College of Animal Experimentation (COBEA).

A quantity of $0.5 \mathrm{ml}$ of blood was collected from each fish by puncture
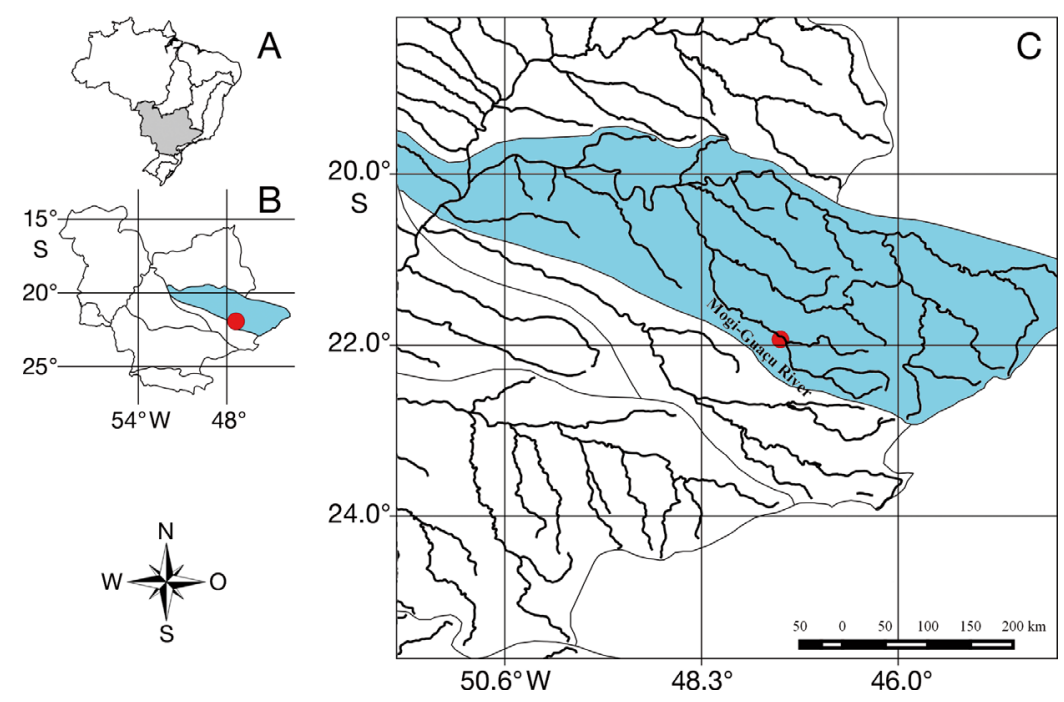

Fig. 1. (A) River basins of Brazil with the Paraná River basin highlighted in grey. (B) Sub-basins of the Paraná River basin with the Mogi-Guaçu River basin (São Paulo state) highlighted in blue. (C) Rivers of the Mogi-Guaçu River basin (blue) and adjacent basins. Collection point (๑) 
Collection of the Zoology Museum of UNICAMP with the voucher number Zue cru 475.

The Mann-Whitney $U$-test was used to analyze differences in intensity of infection, sex and $K_{\mathrm{n}}$ of infested and non-infested fish. The Duncan multiple mean comparison test was used to test the differences in $K_{\mathrm{n}}$. The $t$-test was used to evaluate the hematological parameters between infested and non-infested fish. Spearman's correlation coefficient $\left(\mathrm{r}_{\mathrm{S}}\right)$ was used to evaluate the possible correlation between the abundance of parasites and the weight, length and $K_{\mathrm{n}}$ of the hosts (Zar 2010).

\section{RESULTS}

Of 46 Astyanax altiparanae examined, 28 were female and 18 were male, with total length varying from 9.0 to $14.0 \mathrm{~cm}$ (mean $\pm \mathrm{SD}, 11.5 \pm$ $1.71 \mathrm{~cm})$ and body weight varying from 8.0 to $26.0 \mathrm{~g}(20.6 \pm 14.1 \mathrm{~g})$. The integuments of 21 (45.6\%) fish were infested by Lernaea cyprinacea, with a mean intensity of $4.9 \pm 3.1$ parasites per fish and a mean abundance of 2.2 \pm 3.9 , with a total of 139 recovered crustaceans. Macroscopic lesions associated with parasites in the integument of $A$. altiparanae showed severe inflammation around the site of attachment of the L. cyprinacea specimens (Fig. 2).

There was a positive correlation between abundance $(A)$ of $L$. cyprinacea and the length $(B)\left(\mathrm{n}_{(A+B)}=\right.$ $\left.21, \mathrm{r}_{\mathrm{S}}=0.665, \mathrm{p}=0.0001\right)$ and weight $\left(\mathrm{n}_{(A+B)}=21, \mathrm{r}_{\mathrm{S}}=\right.$ $0.430, \mathrm{p}=0.002$ ) of the hosts. The intensity of infestation was higher in female hosts than in male hosts $\left(\mathrm{n}_{(A+B)}=21, U=0.027, \mathrm{p}=0.05\right)$.

$K_{\mathrm{n}}$, the number of RBCs, and numbers of hematocrit and thrombocytes were higher in non-parasitized fish than in parasitized fish, while hemoglobin concentration, hematimetric indices and white blood cell counts were similar (Table 1). For A. altiparanae, the linear regression of the length-weight relationship of parasitized and non-parasitized fish showed negative allometric growth (Fig. 3), suggesting a greater increase in body mass than in length.

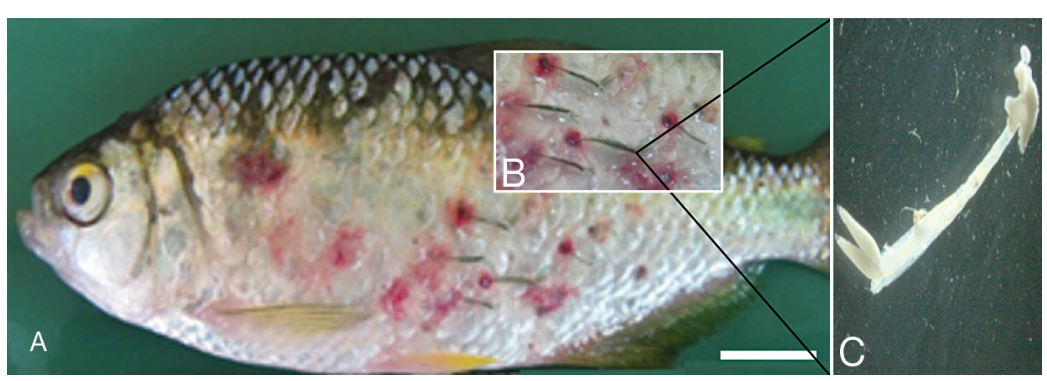

Fig. 2. (A) Astyanax altiparanae from a lagoon in the Mogi-Guaçu River, São Paulo State, Brazil, infested by Lernaea cyprinacea. Scale bar $=1.5 \mathrm{~cm}$. (B) Close up of infested area. (C) Individual parasite

Table 1. Hematological parameters of Astyanax altiparanae from a lagoon in the Mogi-Guaçu River, São Paulo State, Brazil, either non-parasitized or parawith Lernaea cyprinacea. $K_{n}$ : relative condition factor; $M C V$ : mean corcular hemoglobin concentration. Different letters on the same line indicate differences between parasitized and non-parasitized fish according to the $t$-test $(\mathrm{p}<0.05)$

\begin{tabular}{|lcc|}
\hline Parameters & $\begin{array}{c}\text { Non-parasitized fish } \\
(\mathrm{n}=25) \text { Mean } \pm \mathrm{SD}\end{array}$ & $\begin{array}{c}\text { Parasitized fish } \\
(\mathrm{n}=21) \text { Mean } \pm \mathrm{SD}\end{array}$ \\
\hline$K_{\mathrm{n}}$ & $1.06 \pm 0.08^{\mathrm{b}}$ & $0.98 \pm 0.03^{\mathrm{a}}$ \\
Red blood cells $\left(\times 10^{6} \mathrm{\mu l}^{-1}\right)$ & $2.67 \pm 0.48^{\mathrm{b}}$ & $2.43 \pm 0.42^{\mathrm{a}}$ \\
Hematocrit $(\%)$ & $31.0 \pm 3.41^{\mathrm{b}}$ & $20.03 \pm 5.07^{\mathrm{a}}$ \\
Hemoglobin $\left(\mathrm{g} \mathrm{dl}^{-1}\right)$ & $2.23 \pm 0.02^{\mathrm{a}}$ & $2.26 \pm 0.03^{\mathrm{a}}$ \\
$\mathrm{MCV}\left(\mathrm{fl}^{-1}\right)$ & $120.59 \pm 26.77^{\mathrm{a}}$ & $84.01 \pm 22.5^{\mathrm{a}}$ \\
$\mathrm{MCH}(\mathrm{pg})$ & $8.56 \pm 1.61^{\mathrm{a}}$ & $9.64 \pm 1.93^{\mathrm{a}}$ \\
$\mathrm{MCHC}\left(\mathrm{g} \mathrm{dl} \mathrm{l}^{-1}\right)$ & $7.15 \pm 0.79^{\mathrm{a}}$ & $12.01 \pm 2.85^{\mathrm{a}}$ \\
White blood cells $\left(\mu \mathrm{l}^{-1}\right)$ & $31810 \pm 13406^{\mathrm{a}}$ & $38926 \pm 16241^{\mathrm{a}}$ \\
Thrombocytes $\left(\mu \mathrm{l}^{-1}\right)$ & $34795 \pm 15955^{\mathrm{b}}$ & $22200 \pm 11999^{\mathrm{a}}$ \\
\hline
\end{tabular}

Fig. 3. Length-weight relationship for Astyanax altiparanae from a lagoon in the Mogi-Guaçu River, São Paulo State, Brazil, either parasitized (ם) or non-parasitized (@) with Lernaea cyprinacea 


\section{DISCUSSION}

Ectoparasites of fish constitute one of the most significant problems associated with fish farming and fisheries, Lernaea cyprinacea being a major parasite of freshwater fish (Woo \& Shariff 1990, Medeiros \& Maltchik 1999).

In the present study, mean intensity of infestation with L. cyprinacea was moderate in specimens of Astyanax altiparanae from the Mogi-Guaçu River. This finding was similar to results for the same host from a semiarid region of Brazil (Medeiros \& Maltchik 1999). In contrast, infestation levels were lower than those reported by Gallio et al. (2007) for A. altiparanae from a reservoir in Rio Grande do Sul, Brazil. Furthermore, the intensity and abundance of $L$. cyprinacea increased with the growth of hosts, as larger fish had more parasites.

$K_{\mathrm{n}}$ is an indicator of the body condition of fish and is a useful tool for comparing different fish populations (Fajer-Ávila et al. 2011, Guidelli et al. 2011). In the present study, even at a moderate level of infestation, L. cyprinacea was able to induce a decrease in the condition factor of $A$. altiparanae, suggesting that in the case of this fish species, the effects of the parasitism may be more related to the size of the fish than the intensity of the infestation. In contrast, other studies have reported that the abundance of crustacean parasites per fish was not high enough to cause a reduction in the condition factor despite the gill injuries observed (Fajer-Ávila et al. 2011).

RBC parameters can be the fastest way to detect stress and blood loss caused by parasitic infestation in a fish population (Nair \& Nair 1983, Tavares-Dias et al. 2007, Fajer-Ávila et al. 2011, Peña-Rehbein et al. 2013, Ranzani-Paiva et al. 2013). Thus, hematological evaluations have become a routine practice for assessing the health of a fish population. In A. altiparanae infested with $L$. cyprinacea, the decrease in number of RBCs and hematocrit indicated a moderate normocytic-normochromic anemia, similar to that observed by Nair \& Nair (1983) in Channa striatus infested with isopods Alitropus typus.

Piscine thrombocytes are important indicators of the hemostasis status and are thus helpful for evaluating this process in animals. Fish thrombocytes present multifunctionality and are therefore in constant movement between the hematopoietic organs (such as the kidney and spleen) and the bloodstream. The number of these cells in the bloodstream can vary in response to different stimuli (Tavares-Dias \& Moraes 2007, Tavares-Dias et al. 2007, RanzaniPaiva et al. 2013). Thus, in A. altiparanae infested with L. cyprinacea, a decreased number of thrombocytes seems to be due to lesions in the integument of the fish, because these cells have a hemostatic function.

In several fish species, copepod infestations have induced alterations in the number of lymphocytes, neutrophils, eosinophils and monocytes in the blood of the hosts (Nair \& Nair 1983, Silva-Souza et al. 2000, Peña-Rehbein et al. 2013, Ranzani-Paiva et al. 2013). In contrast, in the A. altiparanae from MogiGuaçu infested by L. cyprinacea, no alteration was observed in the total number of leukocytes. However, differing results for other fish species infested with different isopods (Nair \& Nair 1983, Peña-Rehbein et al. 2013) may be due to differences in infestation levels and in parasite strategies.

In conclusion, the present study suggests that infestation with $L$. cyprinacea, even at moderate levels, reduces body condition and leads to normocyticnormochromic anemia, corroborating the importance of these parameters in the evaluation of responses against parasitic infestation with this parasitic copepod. In addition, the results of this study also suggest that, even at moderate levels, infestations with $L$. cyprinacea represents a potential risk to farmed $A$. altiparanae, as, even in such conditions, it can induce important physiological changes in this fish.

Acknowledgements. M.T.D. and E.A.A. were supported by research fellowships from the Conselho Nacional de Pesquisa e Desenvolvimento Tecnológico (CNPq, Brazil). The authors thank Ricardo Torres de Oliveira (CEPTA/ICMBio) for help in dissecting the fish and Dr. Laerte Batista de Oliveira Alves, manager of the National Center for Research and Conservation of Continental Fishes (CEPTA/ICMBio), for support during field work.

\section{LITERATURE CITED}

Bush AO, Lafferty KD, Lotz JM, Shostack AW (1997) Parasitology meets ecology on its own terms: Margolis et al. revisited. J Parasitol 83: 575-583.

Eiras JC, Takemoto RM, Pavanelli GC (2006) Métodos de estudo e técnicas laboratoriais em parasitologia de peixes. Editora Eduem, Maringá

Fajer-Ávila EJ, Guzman-Beltran LG, Zárate-Rodríguez WC, Del Río-Zaragoza OB, Almazan-Rueda P (2011) Pathology caused by adult Pseudochondracanthus diceraus (Copepoda: Chondracanthidae), a parasite of bullseye puffer fish Sphoeroides annulatus. Rev Biol Mar Oceanogr 46:293-302

> Gabrielli MA, Orsi ML (2000) Dispersão de Lernaea cyprinacea (Linnaeus) (Crustacea, Copepoda) na região norte do estado do Paraná, Brasil. Rev Bras Zool 17: 395-399

Gallio M, Silva AS, Monteiro SG (2007) Parasitismo por Lernaea cyprinacea em Astyanax bimaculatus provenientes 
de um açude no município de Antônio Prado, Rio Grande do Sul. Acta Sci Vet 35:209-212

Garutti V, Britski HA (2000) Descrição de uma espécie nova de Astyanax (Teleostei: Characidae) da bacia do alto Rio Paraná e considerações sobre as demais espécies do gênero na bacia. Comum Mus Ciênc Tecnol Sér Zool 13: 65-88

Guidelli G, Tavechio WLG, Takemoto RM, Pavanelli GC (2011) Relative condition factor and parasitism in anostomid fishes from the floodplain of the upper Paraná river, Brazil. Vet Parasitol 177:145-151

Le Cren ED (1951) The length-weight relationship and seasonal cycle in gonadal weight and condition in the perch (Perca fluviatilis). J Anim Ecol 20:201-219

Medeiros ESF, Maltchik L (1999) The effects of hydrological disturbance on the intensity of infestation of Lernaea cyprinacea in an intermittent stream fish community. J Arid Environ 43:351-356

Nair GA, Nair NB (1983) Effect of infestation with isopod Alitropus typus M. Edwards (Crustacea: Flabellifera: Aegidae) on the haematological parameters of the host fish Channa striatus (Bloch). Aquaculture 30:11-19

Nomura H (1975) Fecundidade, maturação sexual e índice gônado-somático de lambaris do gênero Astyanax Baird e Girard, 1854 (Osteichthyes, Characidae), relacionados com fatores ambientais. Rev Bras Biol 35:775-798

Peña-Rehbein P, Ruiz K, Ortloff A, Pizarro MI, Navarrete C (2013) Hematological changes in Eleginops maclovinus during an experimental Caligus rogercresseyi infestation. Rev Bras Parasitol Vet 22:402-406

Raissy M, Sohrabi HR, Rashedi M, Ansari M (2013) Investi-

Editorial responsibility: Anindo Choudhury, De Pere, Wisconsin, USA gation of a parasitic outbreak of Lernaea cyprinacea Linnaeus (Crustacea: Copepoda) in cyprinid fish from Choghakhor lagoon. Iran J Fish Sci 12:680-688

Ranzani-Paiva MJT, Pádua SB, Tavares-Dias M, Egami MI (2013) Métodos para análises hematológicas em peixes. Editora Eduem, Maringá

$>$ Rohde K, Hayward C, Heap M (1995) Aspects of the ecology of metazoan ectoparasites of marine fishes. Int J Parasitol 25:945-970

Silva-Souza AT, Almeida SC, Machado PM (2000) Effect of the infestation by Lernaea cyprinacea Linnaeus, 1758 (Copepoda, Lernaeidae) on the leucocytes of Schizodon intermedius Garavello \& Britski, 1990 (Osteichthyes, Anostomidae). Rev Bras Biol 60:217-220

Tavares-Dias M, Moraes FR (2007) Leukocyte and thrombocyte reference values catfish (Ictalurus punctatus) with an assessment of morphologic, cytochemical and ultrastructural features. Vet Clin Pathol 36:49-54

Tavares-Dias M, Moraes FR, Onaka EM, Rezende PCB (2007) Changes in blood parameters of hybrid tambacu fish parasitized by Dolops carvalhoi (Crustacea, Branchiura), a fish louse. Vet Arh 77:355-363

Thatcher VE (2006) Aquatic biodiversity in Latin America: Amazon fish parasites, 2nd edn. Pensoft Publishers, Sofia

Vazzoler AEAM (1996) Biologia da reprodução de peixes teleósteos: teoria e prática. Editora Eduem, Maringá

> Woo PTK, Shariff M (1990) Lernaea cyprinacea L. (Copepoda: Caligidea in Helostoma temmincki Cuvier \& Valenciennes: the dynamics of resistance in recovered and naive fish. J Fish Dis 13:485-493

Zar JH (2010) Biostatistical analysis, 5th edn. Prentice Hall, Upper Saddle River, NJ

Submitted: December 17, 2015; Accepted: April 21, 2016 Proofs received from author(s): June 9, 2016 